\title{
Probabilistic frequency ratio (PFR) model for quality improvement of landslide susceptibility mapping from LiDAR-derived DEMs
}

\author{
Saied Pirasteh* and Jonathan Li
}

\begin{abstract}
This paper expands the previous efforts by other researchers to present a quantitative and deterministic approach for terrain analysis. This study evaluates both spatial and temporal factors contributing landslides utilizing Light Detection and Ranging (LiDAR) point clouds in conjunction with the frequency ratio model (PFR) than has previously been used in the Alborz Mountains. The study area is Marzan Abad of the Alborz Mountain in Iran. The significance of this study is the performance of a high-resolution digital elevation model (DEM) derived from LiDAR point clouds in order to provide detailed information in improving landslide susceptibility evaluation. This study discusses how we improve the quality of landslide susceptibility evaluation. We apply the PFR model to consider the effect of landslide-related factors associated with Google Earth's high-resolution images and field observations. The LiDAR point cloud data and GIS-based analysis have allowed performing high quality ways of landslide hazard assessments using inventory dataset as compared to previous studies. We contributed an improved landslide inventory map of the Mazandaran Province. We used image elements interpretation from the available ASTER DEM (30 m), LiDAR-DEM (5 m), and the Google Earth high spatial resolution images in conjunction with the field observations. This study evaluates factors such as geology, geomorphology, landuse, soil, slope, and distance from roads and drainage to represent, manipulate, and analyze factors. Also, we evaluated the performance success of the rate curve of landslides susceptibility. The results have indicated an improved landslide susceptibility map from LiDAR-derived DEMs implementing the PFR model with $92.59 \%$ of accuracy performance as compared to the existing data and previous studies in the same region. Furthermore, this study reveals that all considering factors have relatively positive effects on the landslides susceptibility mapping in the study, however, the most effective factor on the landslide occurrence is the lithology with $13.7 \%$.
\end{abstract}

Keywords: Landslide susceptibility, LiDAR, ASTER, GIS, Google Earth high-resolution images, Probabilistic frequency ratio, Alborz mountains

\section{Background}

Landslides are one of the most common deformation scenarios in the real-world environment. Almost every year catastrophic landslides cause loss of lives and result in billions of dollars in property damage around the world. Landslide-prone areas reconnaissance is playing a major role for decision makers to prepare a loss reduction plan. Identification and

* Correspondence: moshaver1380@gmail.com

Mobile Sensing and Geodata Analytics Lab, Department of Geography and Environmental Management, University of Waterloo, Waterloo, Canada spatial distribution of landslides require knowledge of not only geologic and geomorphic processes, but also of state-of-the-art technologies including geographical information system (GIS). Moreover, LiDAR and Unmanned Airborne Vehicle (UAV) techniques have become excellent tools to improve landslide recognition processes for mapping (Haugerud et al. 2003; Eeckhaut and Van, 2007; Liu et al. 2012; Pirasteh and Li 2016).

Numerous research have been attempted on landslide hazards to study slope instability hazards mapping 
(Carrara et al. 1991; Carrara et al. 1999; Guzzetti et al. 1999; Barredo et al. 2000; Pack and Tarboton 2004; Guzzetti et al.2005; Roering et al. 2009; Pirasteh et al. 2011; $\mathrm{Su}$ et al. 2015). Also, some researchers applied deterministic models for landslide susceptibility mapping and modelling (Binaghi et al. 1999; Westen and Terlien 1996; Watts 2004; Sarkar and Kanungo 2004; Pradhan and Pirasteh, 2010; Zhou et al. 2003; Lee and Dan 2005; Lee et al. 2004; Westen et al. 2008; Jebur et al. 2014). Moreover, they have applied the logistic regression model to landslide hazard mapping (Lee and Pradhan 2006; Choi et al. 2012). Recently, landslide hazard evaluation carried out by using fuzzy logic, and artificial neural network models (Lee et al. 2004; Yilmaz 2010; Lee et al. 2014). During the last decade, researchers indicated that landslide susceptibility and deformation measurement have extensively performed particularly for the landslides assessment (Luzi et al. 2000; Schulz 2004; Su and Bork 2006; Streutker and Glenn 2006; Schulz 2007). They have integrated traditional and advanced methods such as classical geodetic surveying techniques (i.e. theodolites, photogrammetry, Global Navigation Satellite Systems (GNSS)), LiDAR, satellite based observation systems, and the GIS technology by applying stochastic and deterministic models. However, the weakness is that the points collected from theodolites, photogrammetry, levels and GNSS, satellite imageries, perform quite low in density. For example, McKean and Roering (2003) studied the low-density digital elevation model (DEM) to determine the potential to differentiate morphologically components within a landslide (Lee and Dan 2005; Glen et al. 2006; Lee and Pradhan 2006; Yilmaz 2010; Niculită 2016). They explored how to provide insight into the material type and activity of the slide. As a result, the literature review indicated that these techniques and low pixel resolutions of DEM and satellite imageries could not provide sufficient enough accuracy to visualize the objects extracting an informative description of the landslide locations and to predict the probability of the landslides occurrence.

In this study, a high-resolution LiDAR DEM (5 m) has associated with the ASTER DEM (15-m spatial resolution). The Google Earth high-resolution images were used in conjunction with the existing spatial distribution inventory landslides map (1:25,000 scale, Natural Resources of Iran) to apply the PFR model. This approach can contribute a new potential method to research scholars improving landslide evaluation and the quality of susceptibility mapping prediction. Therefore, we collected the existing inventory spatial distribution of landslides data, Google Earth's images, LiDAR point clouds, and ASTER data to study landslides probability prediction of the Alborz Mountains in Iran.
The Iranian plateau has potential to earthquakes and of various kinds of landslides (Ali et al. 2003a; Ali et al. 2003b; Ali and Pirasteh 2004; Pirasteh et al. 2009; Jaboyedoff et al. 2012; Pirasteh et al. 2015; Niculită 2016) because of a high tectonic activity, rugged topography, geological setting, and climatologic variety. Most of these landslides occur within two main mountain ranges. They are a) Alborz range with NE-NW trend and b) the Zagros range with NW-SE trend. Landslides risk in Alborz range, particularly in the Central Alborz, has a higher risk than other regions (Shoaei et al. 2005). In the last decades, the study area has experienced landslides in the Central Alborz for example, the Hajiabad- Oshan Road in 2003, Fasham-Meygon road in 2006, and Atashgah-e-Karaj in 2008. Moreover, several landslides and rock fall occurred in the Chalus-Tehran road that was induced by Baladeh-Kojour earthquake on 28th May 2004. These catastrophic landslides have proven that a significant attention with an improved method such as LiDAR high-resolution DEM associated with the PFR approach requires evaluating landslides susceptibility mapping. Therefore, we have selected the Marzan Abad area from the Central Alborz, as it is highly populated area and susceptible to landslides, particularly those of which are triggered by earthquakes.

The objectives of this study are a) to use the LiDAR point clouds of a high-resolution DEM to associate with contributing factors, and b) to improve the quality performance of the PFR model in assessing and predicting landslide susceptible areas in the Central Alborz by evaluating LiDAR point clouds of a high-resolution DEM and other influencing factors. Nevertheless, this study contributes the effectiveness of the LiDAR point clouds on improving the performance of landslide susceptible assessments, and how it increases the quality of the PFR model outcomes. In order to satisfy the above objectives, landslide susceptibility analysis techniques have been applied and verified in the study area using the previous research outcomes. We have also assessed landslide-related factors in the GIS software (ArcGIS 10.4) by implementing the analysis tools for spatial management and data manipulation. Finally, we had achieved an acceptable accuracy of landslide susceptibility map by applying the PFR model when we used a high-resolution of DEM.

\section{Study area}

The Iranian plateau is the part of the Eurasian Plate wedged between Arabian and Indian plates. It situates between the Zagros mountains to the west, the Caspian Sea and the Koppeh Dagh to the north, the Hormuz Strait and the Persian Gulf to the south, and the Hindu Kush to the east. Alborz Mountainous in the north of Iran constitutes a narrow belt of only $100 \mathrm{~km}$ wide. 
These mountains are a part of Alpine-Himalayan system in the western part of Asia which wraps around the South Caspian Sea from the northwest to northeast of Iran (more than $1500 \mathrm{~km}$ ). The study area is located in the Central Alborz at a distance of $30 \mathrm{~km}$ to the Caspian Sea in the north, and $100 \mathrm{~km}$ to the capital city of Tehran in the south. It covers an area of about $1048 \mathrm{~km}^{2}$ and locates between Latitudes $36^{\circ} 15^{\prime} 00^{\prime \prime} \mathrm{N}$ to $36^{\circ} 35^{\prime} 00^{\prime \prime} \mathrm{N}$ and Longitudes $51^{\circ} 07^{\prime} 30^{\prime \prime} \mathrm{E}$ to $51^{\circ} 27^{\prime} 30^{\prime \prime}$ $\mathrm{E}(4,014,000 \mathrm{~N}-4048000 \mathrm{~N}$ and 511184E-541004E in UTM) as presented in Fig. 1.

The elevation of the study area decreases from the south (about $4000 \mathrm{~m}$ ) to the north, in runoff Chalus River. Chalus River is one of the most important rivers in the Central Alborz and cuts the area in the northeast, and is forming a deeply incised valley. This river transfers water from high-lands with annual precipitation less than $400 \mathrm{~mm}$ to the lowlands in the south of the Caspian with annual precipitation of above $1000 \mathrm{~mm}$.

\section{Method}

\section{Data collection and preparation}

Data collection and preparation are the first fundamental and essential step to the landslide hazard analysis. In this study, we composed the GIS database into five parts: 1) Generating of a high-resolution (5 m) LiDAR DEM and $15 \mathrm{~m}$ spatial resolution of the ASTER DEM (VNIR), 2) Google Earth's images, 3) landslide inventory map, 4) landslide predisposing factor maps and topography maps, and 5) Global Positioning System (GPS) data collection from field observations.

The existing landslides inventory spatial distribution of the area (Fig. 1) has given insights to recognize the landslide prone areas. Newly, landslides have been extracted from the LiDAR high-resolution DEM and the ASTER DEM in conjunction with field observations (Fig. 2). The visual image interpretation of the DEMs and Google Earth's images (dated in December 2009, December 2010, December 2011, December 2012, December 2013, December 2014, December 2015, and December 2016)

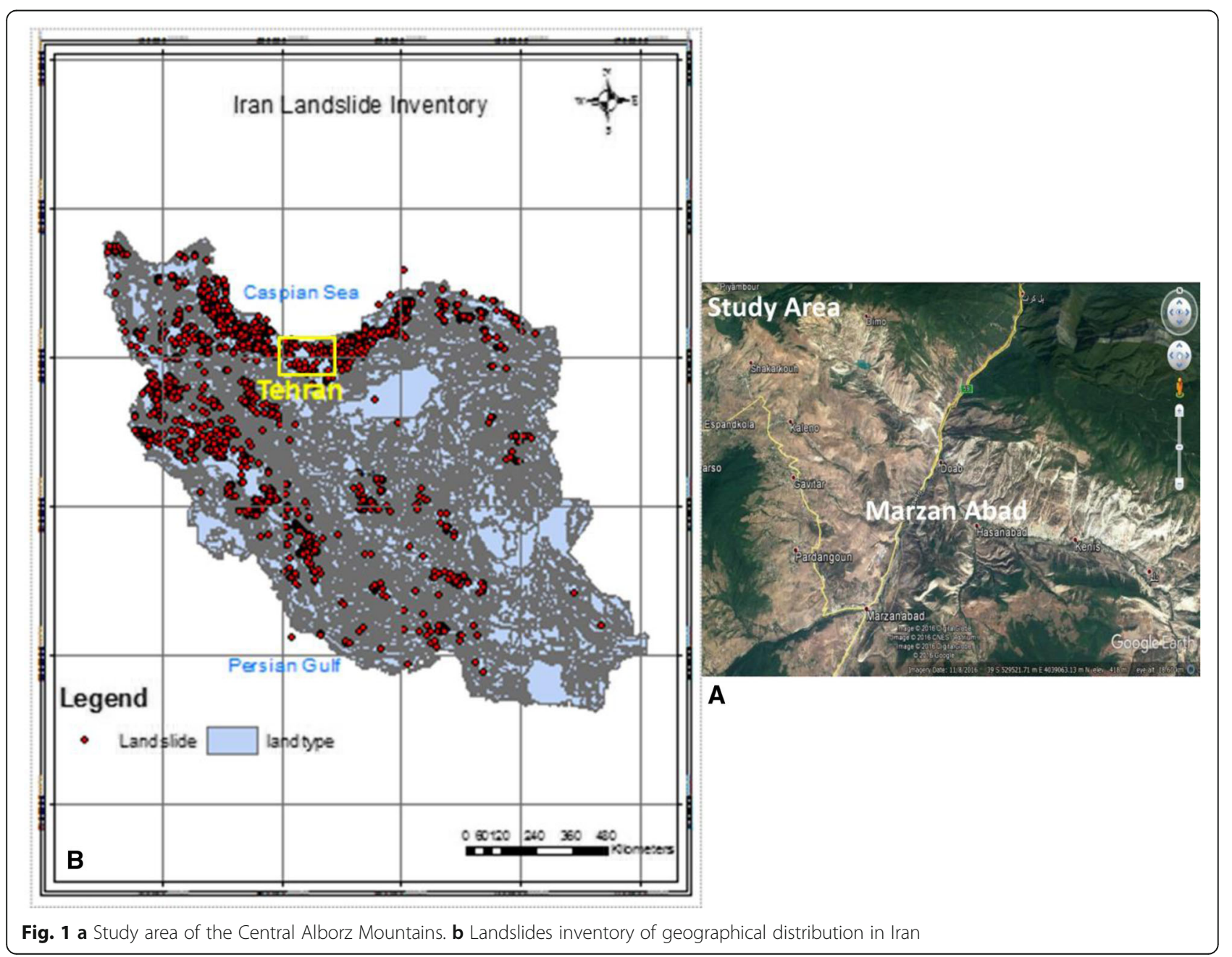



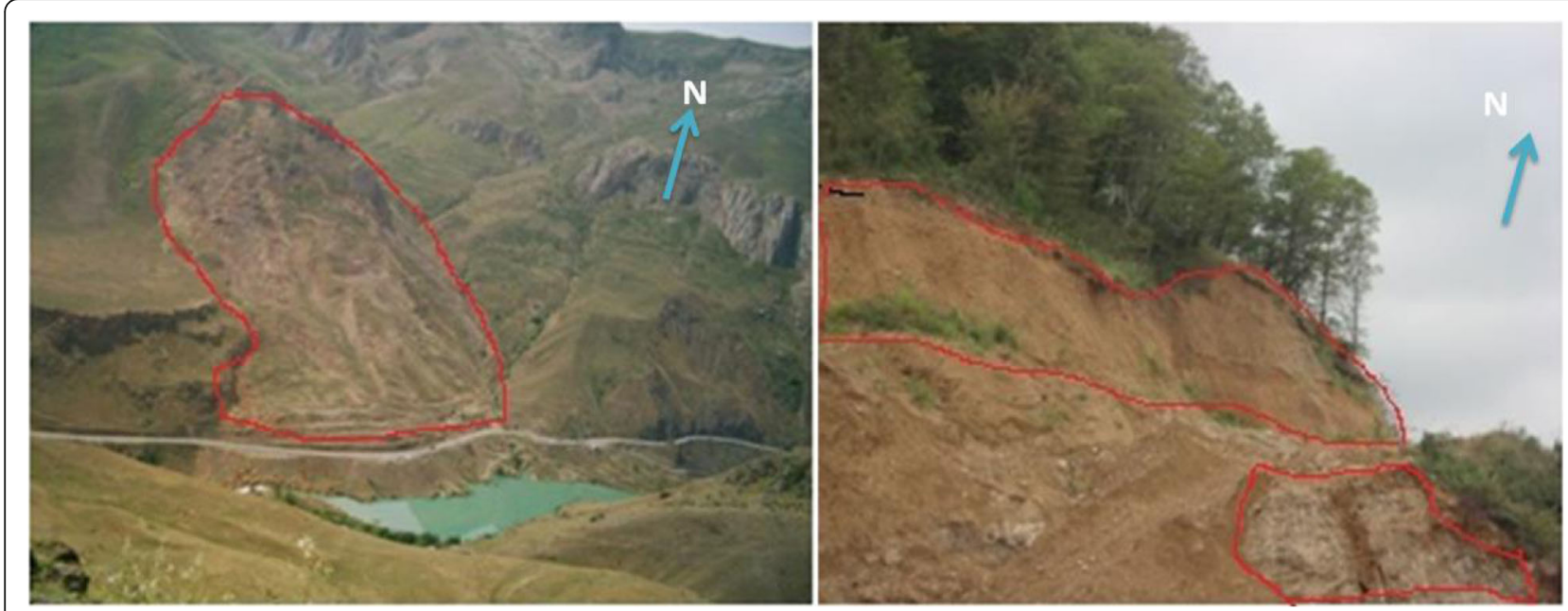

Fig. 2 Landslides in Imamzadeh Ali, Marzan Abad, Central Alborz Mountains

in conjunction with field observations (i.e ground control points (GCPs)) were carried out in the ENVI 4.2 software by using geotechnical and photographic elements. The ENVI 4.2 software allows us to operate a digital image processing (DIP) such as geometric correction, enhancement, and filtering on Google Earth's images.

The landslide susceptibility evaluation requires knowledge of factors leading to landslide analyses. We have determined the influencing factors of the landslides (Varnes 1978; Anbalagan 1992; Brunsden, 1996; Guzzetti et al. 1999; Donati and Turrini 2002; Zhou et al. 2002; Jebur et al. 2014). The reviewed literature and field investigations have identified that the most influencing factors in the study area are: Topography, lithology, soil, geomorphology, steepness of slopes, land use, and distance from road networks and drainage (Nichol and Wong 2005; Metternicht et al. 2005). We have subdivided each category into different classes by its value or feature. All influencing factors have obtained or created in the form of maps, and they are representing large quantities of spatial data. The preparation of a susceptibility mapping involves manipulating, analyzing, and presenting data in the GIS.

In this study, we have prepared the digital geology map of the study area based on a combination of two analog geological sheet maps at 1:100,000 scale, namely Marzan Abad and Chalus, (Geology Survey of Iran 2001) and Google Earth's image interpretation (Fig. 1). We have created the geomorphology map based on the geology and topography map in 1:25,000 scales associated with the ASTER DEM. A slope thematic map was extracted from the LiDAR high-resolution DEM of the area with a spatial resolution of $5 \mathrm{~m}$ (Fig. 3). We collected the soil map (1:25,000 scale) from the Ministry of
Natural Resources of Iran. A field survey has verified the given digital soil map. Road and drainage maps were extracted from the topography map of the study area $(\mathrm{Na}-$ tional Cartographic Center organization) of 1:25,000 scale. The landuse thematic map and the Normalized Difference Vegetation Index (NDVI) of the study area were provided by the Natural Resources of Mazandaran. The landuse map was modified by a field check. Table 1 depicts the summarized information about data layers.

\section{Processing of LiDAR point cloud data}

In spatial analysis measurements, the high-resolution DEM and its derivatives such as slope have been considered for the landslide susceptibility mapping. The highresolution DEM of the Central Alborz is the most useful representation of terrain in the GIS for spatial analysis. A high-resolution DEM is the raster representation, in which each grid cell records the elevation of the earth's surface, and reflects a view of terrain as a field of elevation values. In this study, a resolution of $5 \mathrm{~m}$ in the pixel was applied for grids to generate the high-resolution DEM.

LiDAR point cloud data in LAS format were collected for the Marzan Abad from the Central of Alborz Mountain. We used LAS data to generate a DEM in ArcGIS software. To process the data we used a semi-automated method to remove the noise and classify the objects (Evans et al. 2009). This semi-automated method allowed us to detect and interpret particular objects in the study area. The pre-processing technique has been applied to the point cloud data to achieve the certain level of quality data before it uses for a landslide susceptibility mapping. We extracted the bare-earth (i.e. segregating objects such as trees from the surface and extracting the earth's surface). This process has a direct impact on the quality of 


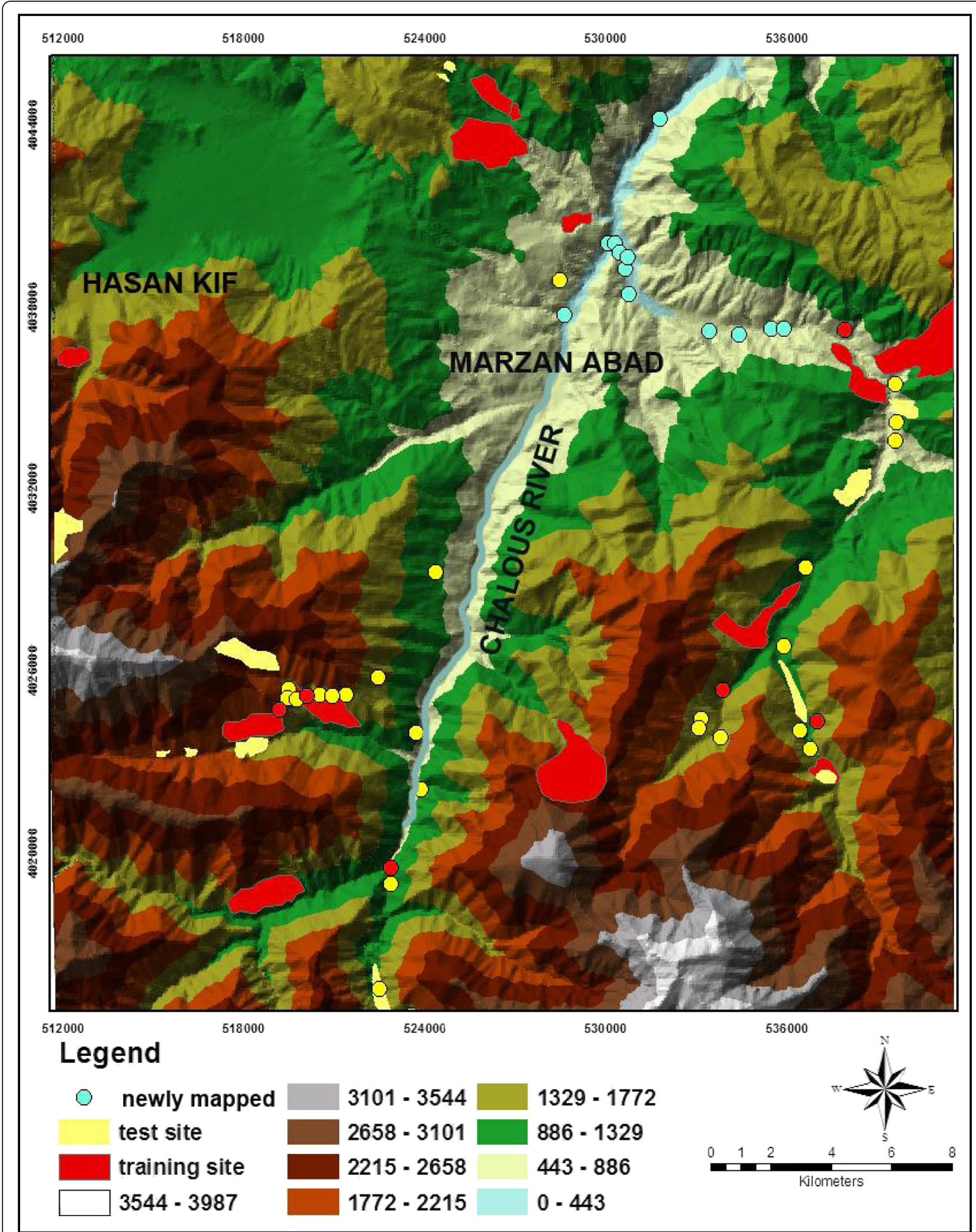

Fig. 3 LiDAR high-resolution TIN. Showing landslides on the triangular irregular network (TIN) model of the study area 
Table 1 Predisposing factors and GIS data in for the study area

\begin{tabular}{|c|c|c|c|c|}
\hline Classification & Sub-Classificat & & GIS Data Type & Scale \\
\hline Geological Hazard & Landslide inve & & Point and polygon coverage & $1: 25,000$ \\
\hline \multirow[t]{8}{*}{ Basic maps } & LiDAR DEM & \multirow[t]{2}{*}{ Slope } & GRID & $5 \times 5 \mathrm{~m}$ \\
\hline & ASTER DEM & & GRID & $15 \times 15 \mathrm{~m}$ \\
\hline & $\begin{array}{l}\text { Topographic } \\
\text { map }\end{array}$ & \multirow[t]{6}{*}{ roads and drainage } & Poly line coverage & $1: 25,000$ \\
\hline & Geology & & Polygon coverage & $1: 100,000$ \\
\hline & Soil & & Polygon coverage & $1: 25,000$ \\
\hline & Landuse & & GRID & $30 \times 30 \mathrm{~m}$ \\
\hline & NDVI & & GRID & $30 \times 30 \mathrm{~m}$ \\
\hline & Geomorpholo & & Polygon coverage & $1: 25,000$ \\
\hline
\end{tabular}

the DEM and landslide investigations. During last decades, various solutions and algorithms for the classification of the LiDAR data were published (Glenn et al. 2006; Derron and Jaboyedoff 2010; Su et al. 2015). The method was based on the surface interpolation and the DEM was generated based on the X,Y,Z points of the whole study area (Pfeifer et al. 1998). To determine the relationship and influence of each individual grid of factors such as landuse etc. within the whole DEM of the study area in the GIS, we are required to consider the whole DEM and the individual factor to identify the number of pixel/grid's contribution to a landslide. We used Hierarchical Robust Filtering (HRF) method and ArcGIS 10.4 software to develop the high-resolution DEM and TIN of the study area (Fig. 3). The HRF method is originally designed for laser data in the vegetated and rugged topography areas such as Central Alborz Mountains.

This algorithm is embedded in the SCOP++ software. The HRF is also called as robust interpolation method and it involves four processing approaches. They are 1) thin out, 2) filter, 3) interpolate, and 4) sort out. The thin out approach is a raster based thinning algorithm. It lays a grid over the complete data and selects one point for each cell. In the filter approach, a DEM is computed, but this time a weighting function. It is used to provide a low to high computational weighting for each cell. The weight function has a half of its maximum value ( $h$ is the half-width value) at $\mathrm{h}$ above round (g). These values determine the steepness of the weight function at a particular point. The cut off refers to " $t$ " in the right tail the weight function (Fig. 4). As for the interpolation, a DEM is derived from the current data set by interpolation approach without differentiating data points. As for the sort out step, we define the distance from the calculated DEM by data points and three iterations. The classifying step has completed the filtering procedure. The major extension of the sort out step was to classify step.

\section{ASTER DEM}

ASTER images are in the form of HDF-EOS. We can work on these images to import them by using the software Ortho-Engine as part of the PCI Gemomatica 9.1. DEMs were generated automatically by using DEM extraction tool from the PCI Gemomatica 9.1. Figure 5 illustrates the flowchart of the methodology employed for ASTER DEM generation. We selected stereo images VNIR nadir and backward images ( $3 \mathrm{~N}$ and $3 \mathrm{~B}$ ) to generated the DEM. A detailed description of the procedure provided by Al-Rousan et al. (1997) and Ulrich et al. (2003). In this study, we collected 23 tie points (TPs) between the stereo-pair because we have not ground control points (GCPs) available. The elevation for some TPs was known. By using the PCI Gemomatica 9.1 we could extract the total RMS of the TPs which is $<1.17$ pixel. The 3D DEM of the study area (Fig. 6) was generated at 30-m pixel resolution with the highest level, and the holes were filled by automated interpolation (Fig. 5). The quality of the ASTER DEM was satisfactory. However, we re-sampled the DEM into $15 \mathrm{~m}$ to exploit the full ortho-image resolution (Al-Rousan et al. 1997; Kamp et al. 2003).

\section{PFR model approach}

In this study, we assumed that future landslides would occur under similar circumstances to those of previous landslides. This study applies the PFR model based on the given assumption. Frequency ratio approach is based on the observed relationships between the distribution of landslides and each landslide-related factor, to reveal the correlation between landslide locations and the factors in the study area (Lee and Pradhan 2006). In order to apply the PFR model, a spatial database of landsliderelated factors was constructed in the GIS platform. All 


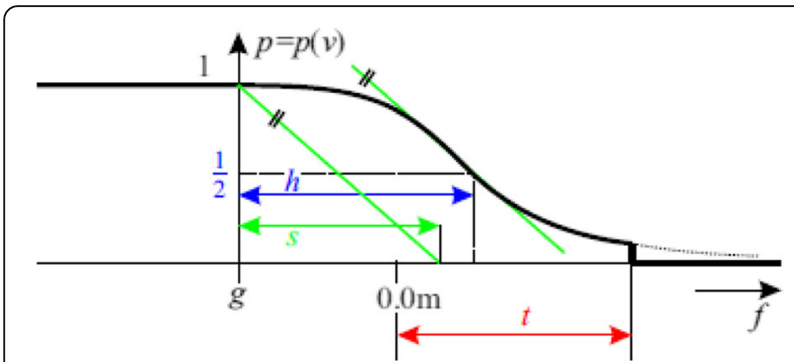

Fig. 4 Weight function (Pfeifer et al., 1998)

data layers (Table 1) were converted to the GIS format and were geo-referenced into the Universal Transverse Mercator (UTM) coordinate system, and maps have represented each factor in the GIS environment (Fig. 7).

Then we construct maps of various factors in different classes. A fine grid was overlaid over the study area. Each grid cell represents a small unit area (rasterization). The data layers have obtained a square-grid matrix with 3400 lines by 2982 columns, and each pixel represented $5 \times 5 \mathrm{~m}$ area on the ground (Fig. 3). By utilizing the overlay of training subsets of landslides, geospatial distribution map, and different predisposing factors' ranges such as topography, the spatial relationship between landslide locations and each factor's range was extracted. The numbers of landslide occurrence pixels in each class were evaluated, then the Frequency Ratio (FR) value for each factor's range was calculated. It allows dividing the occurrence landslide ratio by the area ratio. Landslide frequency ratio can be calculated by the ratio of percent domain of a factor class and percent landslide in that class. Then the frequency ratio (FR) method has implemented to evaluate the rank of correlation between the selected factor's ranges (i.e. slope, land use, soil,

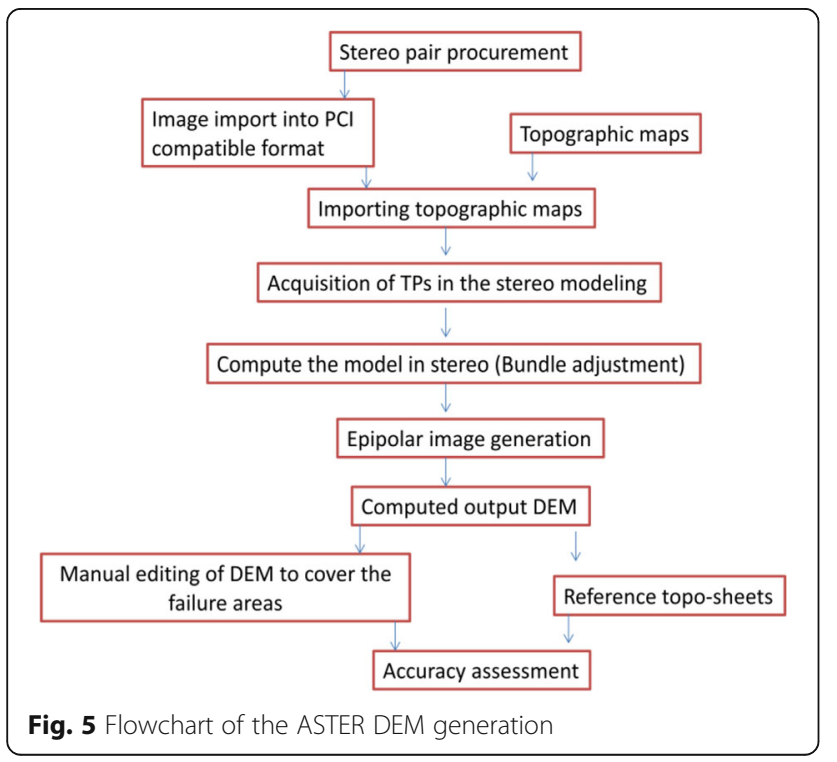

lithology, distance from drainage, and distance from the road network) and landslide locations in the study area. The value of 1 for FR value is an average value. In this study, we defined that the greater ratio above the unity means the stronger correlation is between the selected factors and landslides geographical distribution. Likewise, the lower ratio than unity means we have a lower correlation between landslide occurrence and the given factors attribute. Therefore, based on the calculated FR values, the relation of each category's factor with landslide occurrences have been evaluated. After the FR values calculation, we calculated the Landslide Susceptibility Index (LSI) for each pixel of the study area. This method considers a point $\mathrm{x}$ with $\mathrm{m}$ (number of layers) pixel values $(\times 1, \ldots, x m)$ in the study area. In pixel $x$, LSI can be calculated by summation pixel values $(\times 1, \ldots$, $\mathrm{xm})$, as indicated by the following equation:

$$
L S I=\sum \operatorname{Fr}_{(1, \ldots m)}
$$

\section{Performance of the effect analysis}

One of the fundamental steps in the FR approach and the landslide susceptibility mapping process is validation. We have applied the authentic process to determine the reliability of the previous data and parameters that involve in the present study. We obtained the data from the Geological Survey of Iran and the National Geoscience Database of Iran. We have verified the performance of our result by comparing the existing landslide inventory geospatial distribution map with the landslide susceptibility map (a cross-validation technique). Previous studies (Dietrich et al. 1995; Duan and Grant 2000; Lee and Dan 2005; Liu et al. 2012; Jebur et al. 2014) used "success rate" to evaluate the model performance. The success rate is defined as a ratio of how many actual landslide sites are successfully predicted and allow us to estimate the goodness of the fit of the predictive models with actual landslide sites.

In this study, the results of the landslide susceptibility analysis and the prepared landslide prediction map have verified using the test subset of landslides for the same study areas. Test subset includes unconsidered landslide locations (20\% of all) and some newly mapped landslides through image interpretation and ground truth observations with the help of the Global Positioning System (GPS) (Fig. 8). Intersections between the prediction image and total landslide locations allowed us to compute the number of occurred landslides in each LSI values. However, the method could determine the performance of the output information, and the approach has improved the method of landslide evaluation for susceptibility mapping utilizing the LiDAR high-resolution DEM. 


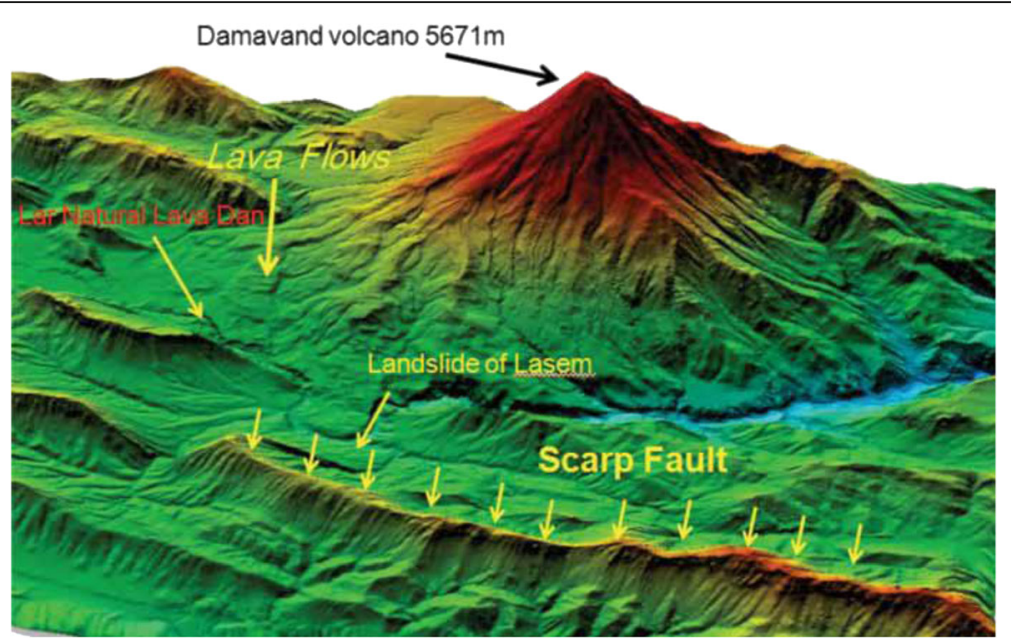

Fig. 6 3D of the ASTER DEM of the Central Alborz shows scarp fault and lanslide of Lasem in the study area
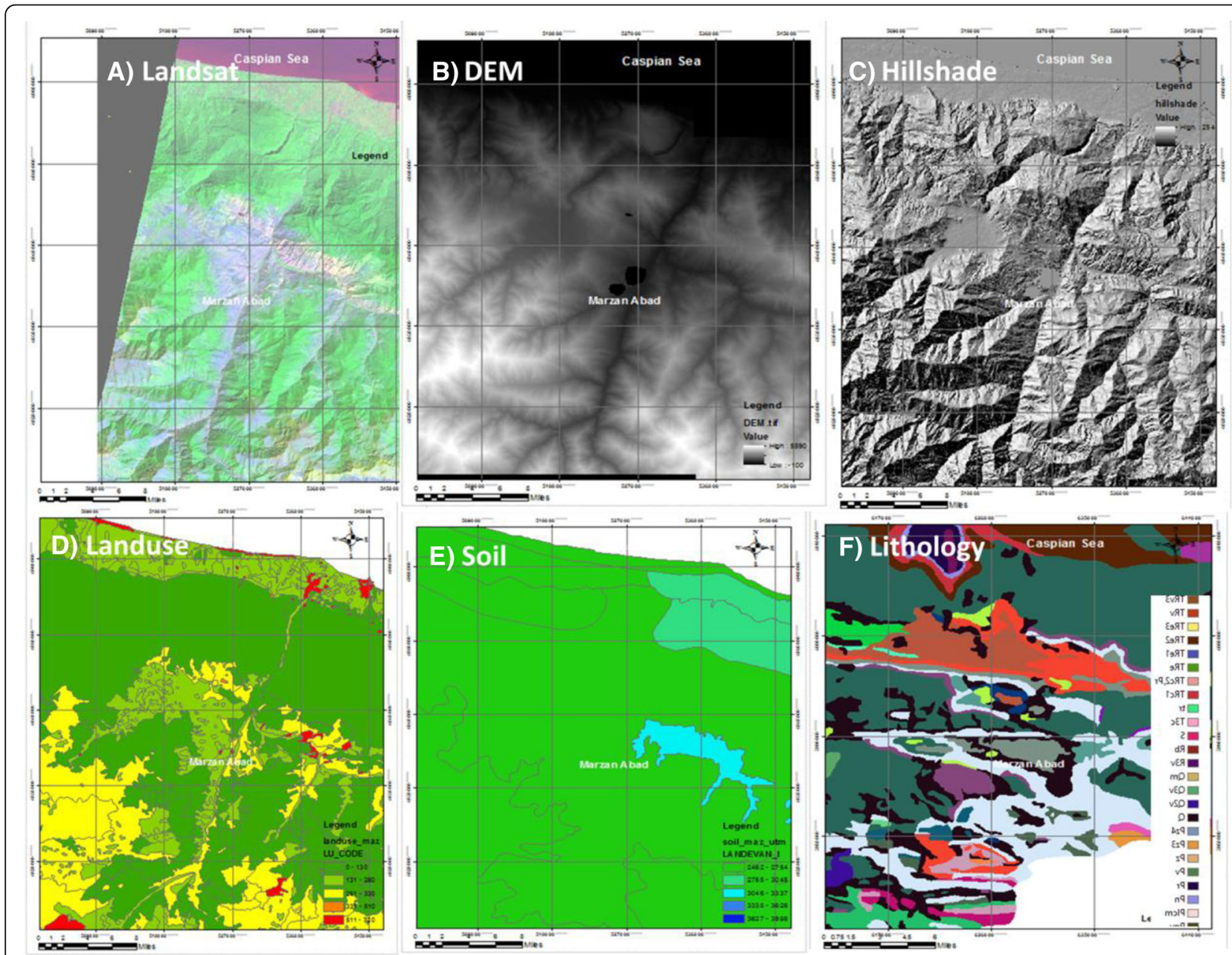

Fig. 7 Represents influencing factors and maps in the GIS environment. a Landsat TM satellite image, (b) DEM, (c) hillshaded, (d) Landuse, (e) Soil, and (f) lithology of Marzan Abad and study area 


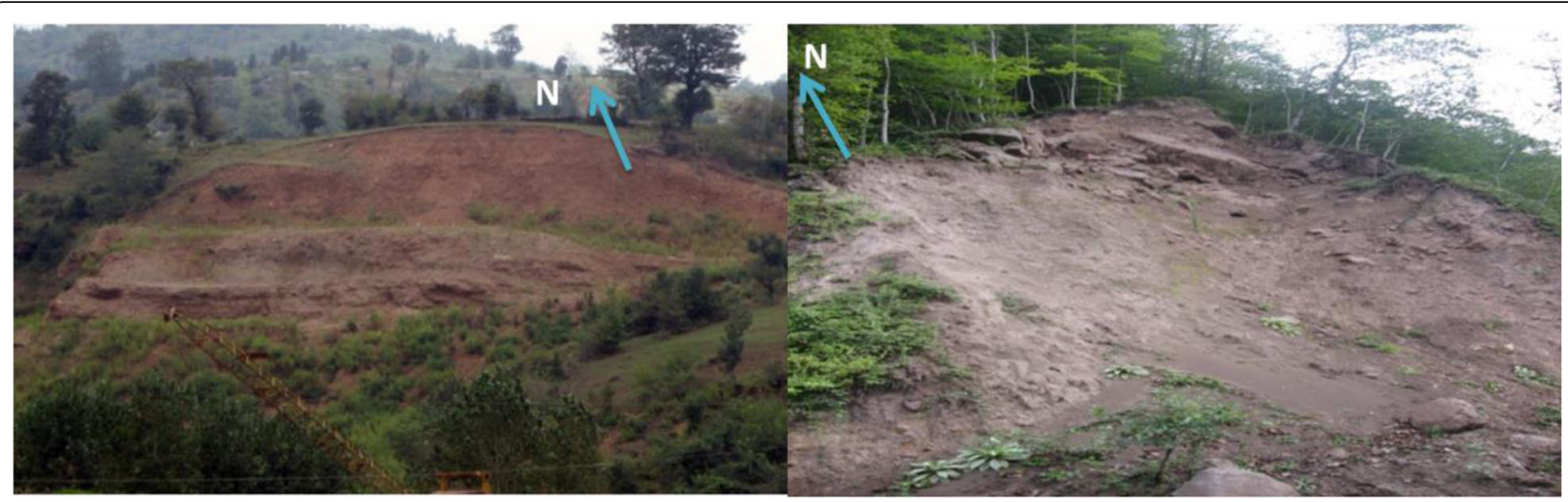

Fig. 8 Field observations and newly mapped landslides verified landsides extraction from the raster image interpretation of the LiDAR high-resolution DEM

Nevertheless, a far less conventional procedure in conjunction with the state-of-the-art technologies such as LiDAR high-resolution data and PFR method results in a much more satisfying outcome for all concerned. The calculated index values of cells sorted in descending order to obtain the success rate of the curve. We divided the ordered cell values into hundred classes and accumulated $1 \%$ intervals to present the percentage of landslides in the study area. Also, some landslide occurrence in each Index value are representing as a percentage of total landslides cumulatively. Effect analysis studies have associated with the high-resolution of DEM and landslide influencing factors indicated how a solution could change when the input factors are changed. This analysis quantifies the uncertainty of each factor. In this study, the effect analyses have been conducted by the exclusion of each factor in turn during the summation stage using Eq. 1. However, the effect of each contributed factor evaluates the related success rates by using the area under the curve calculation.

\section{Results and discussion}

PFR model and factors analysis: an improved landslides susceptibility map

We used LiDAR point clouds DEM and ASTER DEM to identify newly landslides from existing inventory dataset in conjunction with the field observations. The highresolution of LiDAR DEM has a better performance identifying new landslides than ASTER DEM, and also implementing the PFR model from LiDAR DEM demonstrates an acceptance precision and quality of the susceptibility mapping. The study shows that geology is playing a major role in controlling factors for landslides in the Central of Alborz since the geology of this area is very complex. Lithologically, the study area comprises several formations as depicted in Table 2. The FR calculations (Table 3) results that the highest FR values are the most susceptible groups for landslides occurrence.
They belong to areas with some geological layers outcrops such as $\mathrm{Q}_{1}, \mathrm{~K}_{11}, \mathrm{P}_{\mathrm{n}}, \mathrm{K}_{\mathrm{M} 2}$, and $\mathrm{K}_{1 \mathrm{M} 2}$ (FR: 39.5, 9.0, $3.3,1.5$, and 1.5 , respectively).

These groups are mainly including marl, marl limestone, limestone, shale associated with old landslides, and rock stream traces which mostly are fissile, soluble and easily weathered materials. The lowest FR values $(F R=0)$ belong to geological groups including $J_{1}, T^{2} J_{s}$, $\mathrm{P}_{\mathrm{d}}, \mathrm{E}_{\mathrm{d}}, \mathrm{E} 1, \mathrm{O}_{1}, \mathrm{P}_{1 \mathrm{q}}$, and $\mathrm{PE}_{\mathrm{e}}$. FR values are showing a very low correlation with landslide occurrence (Table 3). Thus, we predict a very low susceptibility of landslide occurrence in these classes. The strata mostly contain dolomite, cherty dolomite sandstone, siltstone, and quartzite. We identified that they are among the resistance and hard fracturing litho units in the study area.

Landuse map has indicated that the most hazardous classes are in the lake area (coastal landslides), agricultural lands, and grasslands (FR value 3.8, 2.6, and 1.3, respectively). It is because of geological characteristics $\left(\mathrm{K}_{1 \mathrm{M} 2}\right.$ and $\mathrm{Q}_{1}$ ) and water influences in the coastal area. Thus we expect a higher FR values than other locations. In the study area, the agricultural lands are controversial because the landuse and landcover situation of Marzan Abad area at the time of failure is unknown. Moreover, it is not possible to know whether the presence of agricultural lands was a cause of failure or consequence. In fact, it is also possible to possibly say the changes in steepness are due to the evolution of the scarps that may have favored with agricultural lands. This study shows that deep soils from alluvial and fine alluvial soils are the most susceptible groups for landslide occurrence with FR > 2. Geomorphologically, deep valleys and debris lands are the most susceptible classes with FR $>2$. Alluvial fan and alluvial plain area have the lowest susceptibility of landslide occurrence with FR $=0$ that we have not expected.

The relationships between landslide occurrences and the slope show that gentle slopes have a low frequency 
Table 2 Different formations and lito-units in the study area

\begin{tabular}{|c|c|c|c|c|c|c|}
\hline \multirow[t]{2}{*}{ Ara } & \multirow[t]{2}{*}{ Period } & \multirow[t]{2}{*}{ Formation } & \multirow[t]{2}{*}{ Code } & \multirow[t]{2}{*}{ Lithology } & \multicolumn{2}{|c|}{ Area covered } \\
\hline & & & & & $\left(\mathrm{KM}^{2}\right)$ & $\%$ \\
\hline \multirow[t]{10}{*}{ Paleozoic } & $\begin{array}{l}\text { Up-Pre. } \\
\text { Cambrian }\end{array}$ & KAHAR & $P E_{K}$ & $\begin{array}{l}\text { Salty shale, sandstone, minor dolomite, } \\
\text { quartzite }\end{array}$ & 148.33 & 14.64 \\
\hline & \multirow[t]{3}{*}{ Cambrian } & SOLTANIEH & PEe & $\begin{array}{l}\text { Thick bedded to massive light-colored } \\
\text { dolomite, locally with chert bands }\end{array}$ & 53.64 & 5.30 \\
\hline & & BARUT & $E_{b}$ & $\begin{array}{l}\text { Micaceous variegated siltstone and shale, } \\
\text { cherty dolomite intercalations }\end{array}$ & 8.8 & 0.87 \\
\hline & & LALUN & $E_{1}$ & Red arkosic sandstone & 19.77 & 1.95 \\
\hline & Ordovician & MILA & $\mathrm{O}_{1}$ & $\begin{array}{l}\text { Sandstone, shale, limestone, marl phosphatic } \\
\text { layers }\end{array}$ & 2.08 & 0.21 \\
\hline & Carboniferous & MOBARAKL & $C_{M}$ & $\begin{array}{l}\text { Black limestone, dolomitic limestone, marl } \\
\text { intercalations }\end{array}$ & 80.38 & 7.94 \\
\hline & \multirow[t]{4}{*}{ Permian } & \multirow[t]{2}{*}{ DORUD } & $P_{d}$ & $\begin{array}{l}\text { Sandstone, shale, limestone intercalatoins, } \\
\text { quartzite, siltstone }\end{array}$ & 26.93 & 2.66 \\
\hline & & & $P_{V}$ & Basic flows, pyroclastics, sandstone & 0.99 & 0.10 \\
\hline & & RUTEH & $\mathrm{P}_{\mathrm{r}}$ & Fusulina limestone, dolomitic limestone & 43.97 & 4.34 \\
\hline & & NESEN & $P_{n}$ & $\begin{array}{l}\text { Cherty limestone, marly limestone, marl } \\
\text { and sandy shale }\end{array}$ & 3.88 & 0.38 \\
\hline \multirow[t]{11}{*}{ Mesozoic } & \multirow[t]{2}{*}{ Triassic } & \multirow[t]{2}{*}{ ELIKA } & $\mathrm{TR} \mathrm{em}_{\mathrm{m}}$ & $\begin{array}{l}\text { Thin-bedded limestone, calcareous shale, } \\
\text { quartzitic sandstone }\end{array}$ & 2.77 & 0.27 \\
\hline & & & $T R_{d c}$ & Massive dolomite & 36.04 & 3.56 \\
\hline & \multirow[t]{2}{*}{ Jurassic } & SHEMSHAK & $\mathrm{TR}_{3} \mathrm{~J}_{\mathrm{S}}$ & $\begin{array}{l}\text { Shale, sandstone, siltstone, claystone, } \\
\text { quartzite, conglomerate, locally limestone } \\
\text { intercalations: coal seams and lenses }\end{array}$ & 179.45 & 15.28 \\
\hline & & LAR & $J_{1}$ & Limestone, locally dolomitic limestone & 8.35 & 0.82 \\
\hline & \multirow[t]{7}{*}{ Cretaceous } & TIZ_KUH & $K_{1}$ & Orbitolina limestone (Apian - Cenomanian) & 31.09 & 3.06 \\
\hline & & CHALUS & $\mathrm{K}_{11}$ & Limestone (Berriasian - Valanginian) & 2.04 & 0.20 \\
\hline & & & $\mathrm{K}_{\mathrm{v} 21}$ & $\begin{array}{l}\text { Alkali basalt, spilitic basalt conglomerate, } \\
\text { tuff braccia, tuff }\end{array}$ & 71.05 & 6.07 \\
\hline & & & $\mathrm{K}_{\mathrm{V} 22}$ & $\begin{array}{l}\text { Trachyandesitic basalt, tuff breccia, } \\
\text { pyroclastics, tuffite }\end{array}$ & 41.58 & 4.10 \\
\hline & & & $\mathrm{K}_{12}$ & Globotruncana limestone, marl limestone & 69.77 & 6.89 \\
\hline & & & $\mathrm{K}_{\mathrm{M} 2}$ & Marl, calcareous marl, marly limestone & 51.11 & 5.05 \\
\hline & & & $\mathrm{K}_{1 \mathrm{M} 2}$ & Alternations of limestone and marl & 33.06 & 3.26 \\
\hline \multirow[t]{5}{*}{ Cenozoic } & Tertiary & & P1Q & $\begin{array}{l}\text { Conglomerate, sandstone, siltstone, } \\
\text { siltymarl }\end{array}$ & 28.28 & 2.74 \\
\hline & \multirow[t]{4}{*}{ Quaternary } & & Q & $\begin{array}{l}\text { Undifferentiated young \& old alluvial fans, } \\
\text { traces, colluvium, residual soils, fill valley } \\
\text { sediments lake deposits }\end{array}$ & 90.81 & 8.90 \\
\hline & & & Q1 & Landslide and rock stream & 11.48 & 1.13 \\
\hline & & & river and lake & Water body, terraces, colluvium, residual soil & 2.80 & 0.27 \\
\hline & & & total & & 1048.45 & 100.00 \\
\hline
\end{tabular}

of landslides because they have a lower shear stress. We found that at a slope of $10^{\circ}$ or less, the frequency ratio was below 1. It is indicating a low probability of landslide occurrence. However, slopes above $11^{\circ}$ have a ratio of $>1$ are showing a higher likelihood of landslide occurrence. The areas with slope steepness of more than $40^{\circ}$ and cover a less than $4 \%$ of the area are mostly covered by bedrocks (i.e. volcanic rocks). However, this part of the study area with slope steepness of more than $40^{\circ}$ have a lower probability of a landslide.

This study reveals that road networks have a strong relationship with landslide occurrence because of cut-slope creations through roads construction. We found that the closer distance to the road, the greater the chances of a landslide occurring. The distance of $<100 \mathrm{~m}$, are the most susceptible class with FR $>3$, and areas with a distance of 
Table 3 Frequency ratio of factors to landslide occurrence

\begin{tabular}{|c|c|c|c|c|c|c|}
\hline \multirow[t]{2}{*}{ Factor } & \multirow[t]{2}{*}{ Class } & \multicolumn{2}{|c|}{ Total number of pixel } & \multicolumn{2}{|c|}{ Landslide occurrence pixel } & \multirow{2}{*}{$\begin{array}{l}\text { Frequency } \\
\text { ratio }\end{array}$} \\
\hline & & Number $^{a}$ & $\%$ & Number $^{b}$ & $\%$ & \\
\hline \multirow[t]{9}{*}{ Soil } & Weathered & 85,091 & 0.84 & 0 & 0.00 & 0.00 \\
\hline & $\begin{array}{l}\text { Medium soil form } \\
\text { alluvial }\end{array}$ & 804,145 & 7.94 & 0 & 0.00 & 0.00 \\
\hline & Thin soil over rock & 658,226 & 6.50 & 15,979 & 7.80 & 1.20 \\
\hline & $\begin{array}{l}\text { Medium soil over } \\
\text { the rock }\end{array}$ & $2,185,002$ & 21.57 & 80 & 0.04 & 0.00 \\
\hline & $\begin{array}{l}\text { Medium soil over } \\
\text { colluvial }\end{array}$ & $1,746,851$ & 17.24 & 60,913 & 29.72 & 1.72 \\
\hline & $\begin{array}{l}\text { Deep soil from } \\
\text { alluvial }\end{array}$ & 111,793 & 10.32 & 5300 & 2.59 & 2.34 \\
\hline & Fine alluvial soils & $1,045,712$ & 3.45 & 45,430 & 22.17 & 2.15 \\
\hline & Thin sandy soils & 349,206 & 31.04 & 1939 & 0.95 & 0.27 \\
\hline & Rocks & $3,145,180$ & 1.10 & 75,275 & 36.73 & 1.18 \\
\hline \multirow{5}{*}{$\begin{array}{l}\text { Distance from } \\
\text { drainage }(m)\end{array}$} & 100 & $4,424,123$ & 43.67 & 76,569 & 37.36 & 0.86 \\
\hline & 200 & $2,464,779$ & 24.33 & 59,288 & 28.93 & 1.19 \\
\hline & 400 & $2,222,416$ & 21.94 & 53,917 & 26.31 & 1.20 \\
\hline & 800 & 987,245 & 9.75 & 15,042 & 7.34 & 0.75 \\
\hline & $>800$ & 40,237 & 0.40 & 100 & 0.05 & 0.12 \\
\hline \multirow{7}{*}{$\begin{array}{l}\text { Slope } \\
\text { (degree) }\end{array}$} & $0-5$ & 490,045 & 4.83 & 3442 & 1.68 & 0.35 \\
\hline & $5-10$ & 669,427 & 6.60 & 12,333 & 6.02 & 0.91 \\
\hline & $10-20$ & $2,746,384$ & 27.09 & 67,408 & 32.89 & 1.21 \\
\hline & $20-30$ & $3,200,304$ & 31.56 & 67,151 & 32.77 & 1.05 \\
\hline & $30-40$ & $2,530,305$ & 24.96 & 47,358 & 23.11 & 0.94 \\
\hline & $40-50$ & 453,592 & 4.47 & 6937 & 3.38 & 0.76 \\
\hline & $>50$ & 48,743 & 0.48 & 310 & 0.15 & 0.31 \\
\hline \multirow[t]{16}{*}{ Lithology } & TRem & 27,679 & 0.27 & 785 & 0.36 & 1.33 \\
\hline & PEE & 536,418 & 5.30 & 2 & 0.00 & 0.00 \\
\hline & $\mathrm{Pn}$ & 38,776 & 0.38 & 2735 & 1.27 & 3.31 \\
\hline & $\operatorname{Pr}$ & 439,706 & 4.34 & 5295 & 2.45 & 0.56 \\
\hline & PV & 9875 & 0.10 & 39 & 0.02 & 0.19 \\
\hline & Q & 901,467 & 8.90 & 10,859 & 5.02 & 0.56 \\
\hline & Q1 & 114,961 & 1.13 & 96,880 & 44.81 & 39.49 \\
\hline & TR3JS & 1,547,999 & 15.28 & 654 & 0.30 & 0.02 \\
\hline & $\mathrm{K} 1 \mathrm{M} 2$ & 330,740 & 3.26 & 10,652 & 4.93 & 1.51 \\
\hline & $\mathrm{KM} 2$ & 511,173 & 5.05 & 16,768 & 7.76 & 1.54 \\
\hline & KV22 & 415,791 & 4.10 & 12,040 & 5.57 & 1.36 \\
\hline & P1Q & 277,810 & 2.74 & 0 & 0.00 & 0.00 \\
\hline & $\mathrm{Pd}$ & 269,380 & 2.66 & 42 & 0.02 & 0.01 \\
\hline & TRdc & 360,447 & 3.56 & 764 & 0.35 & 0.10 \\
\hline & $C M$ & 804,135 & 7.94 & 11,461 & 5.30 & 0.67 \\
\hline & $\mathrm{O} 1$ & 20,800 & 0.21 & 0 & 0.00 & 0.00 \\
\hline \multirow[t]{2}{*}{ Factor } & Class & \multicolumn{2}{|c|}{ Total number of pixel } & \multicolumn{2}{|c|}{ Landslide occurrence pixel } & Class \\
\hline & & Number $^{a}$ & $\%$ & Number $^{b}$ & $\%$ & \\
\hline \multirow[t]{2}{*}{ Lithology } & E1 & 197,786 & 1.95 & 0 & 0.00 & 0.00 \\
\hline & $\mathrm{Eb}$ & 87,995 & 0.87 & 1 & 0.00 & 0.00 \\
\hline
\end{tabular}


Table 3 Frequency ratio of factors to landslide occurrence (Continued)

\begin{tabular}{|c|c|c|c|c|c|c|}
\hline & PEK & $1,483,288$ & 14.64 & 6760 & 3.13 & 0.21 \\
\hline & J1 & 83,479 & 0.82 & 147 & 0.07 & 0.08 \\
\hline & K1 & 309,512 & 3.06 & 1364 & 0.63 & 0.21 \\
\hline & K11 & 20,444 & 0.20 & 3925 & 1.82 & 9.00 \\
\hline & $\mathrm{K} 12$ & 697,915 & 6.89 & 10,374 & 4.80 & 0.70 \\
\hline & kv21 & 614,502 & 6.07 & 13,330 & 6.17 & 1.02 \\
\hline & river & 25,575 & 0.25 & 0 & 0.00 & 0.00 \\
\hline & lake & 2424 & 0.02 & 64 & 0.03 & 1.24 \\
\hline \multirow[t]{7}{*}{ Land use } & Agriculture land & $1,467,497$ & 14.49 & 78,969 & 38.53 & 2.66 \\
\hline & Settlement & 407,629 & 4.02 & 9869 & 4.82 & 1.20 \\
\hline & Open Vegetation & $2,914,371$ & 28.77 & 49,777 & 24.29 & 0.84 \\
\hline & Lake & 2101 & 0.02 & 163 & 0.08 & 3.84 \\
\hline & Grass land & $1,395,207$ & 13.77 & 36,045 & 17.59 & 1.28 \\
\hline & Dense vegetation & $3,385,573$ & 33.42 & 30,078 & 14.68 & 0.44 \\
\hline & Bad land & 558,122 & 5.51 & 38 & 0.02 & 0.00 \\
\hline \multirow[t]{6}{*}{ Distance from road (m) } & 50 & 226,534 & 2.23 & 15,779 & 7.70 & 3.45 \\
\hline & 100 & 223,772 & 2.21 & 14,477 & 7.06 & 3.20 \\
\hline & 200 & 428,101 & 4.22 & 20,930 & 10.21 & 2.42 \\
\hline & 400 & 784,725 & 7.74 & 30,603 & 14.93 & 1.93 \\
\hline & 800 & $1,344,647$ & 13.26 & 31,178 & 15.21 & 1.15 \\
\hline & $>800$ & $7,131,021$ & 70.33 & 91,972 & 44.88 & 0.64 \\
\hline \multirow[t]{8}{*}{ Geomorphology } & Debris land & 255,864 & 2.53 & 15,629 & 7.23 & 2.86 \\
\hline & Deep valley & 670,098 & 6.61 & 45,181 & 20.90 & 3.16 \\
\hline & Limestone Relief & $1,373,183$ & 13.56 & 3040 & 1.41 & 0.10 \\
\hline & Moderate Relief & $2,238,436$ & 22.10 & 58,355 & 26.99 & 1.22 \\
\hline & Alluvial Fan & 263,711 & 2.60 & 0 & 0.00 & 0.00 \\
\hline & Alluvial Plain & 385,201 & 3.80 & 0 & 0.00 & 0.00 \\
\hline & Alluvial Terrace & 311,277 & 3.07 & 10,000 & 4.63 & 1.51 \\
\hline & Volcano Relief & $4,632,287$ & 45.73 & 72,711 & 33.64 & 0.74 \\
\hline
\end{tabular}

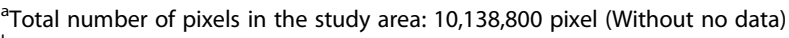

${ }^{\mathrm{b}}$ Total number of landslide occurrence pixel: 204,939 pixel (Estimation group)

Table 4 Statistics of the LSI value for all cases

\begin{tabular}{llllll}
\hline & Min. value & Max. value & Mean value & Std. & AUC ratio \\
\hline Except drainage & 1.5 & 53.87 & 5.95 & 5.01 & 0.925 \\
Except soil & 1.8 & 53.34 & 5.95 & 4.85 & 0.915 \\
Except slope & 1.52 & 53.86 & 5.95 & 5.01 & 0.924 \\
Except road & 1.66 & 52.05 & 5.95 & 48.7 & 4.83 \\
Except landuse & 1.85 & 52.41 & 5.95 & 5.909 \\
Except geology & 2.21 & 13.83 & 5.95 & 6.93 & 0.920 \\
Except geomorphology & 1.56 & 51.91 & 6.95 & 5.81 & 0.789 \\
Total factors & 2.3 & 55.07 & & 5.02 & 0.921 \\
\hline
\end{tabular}




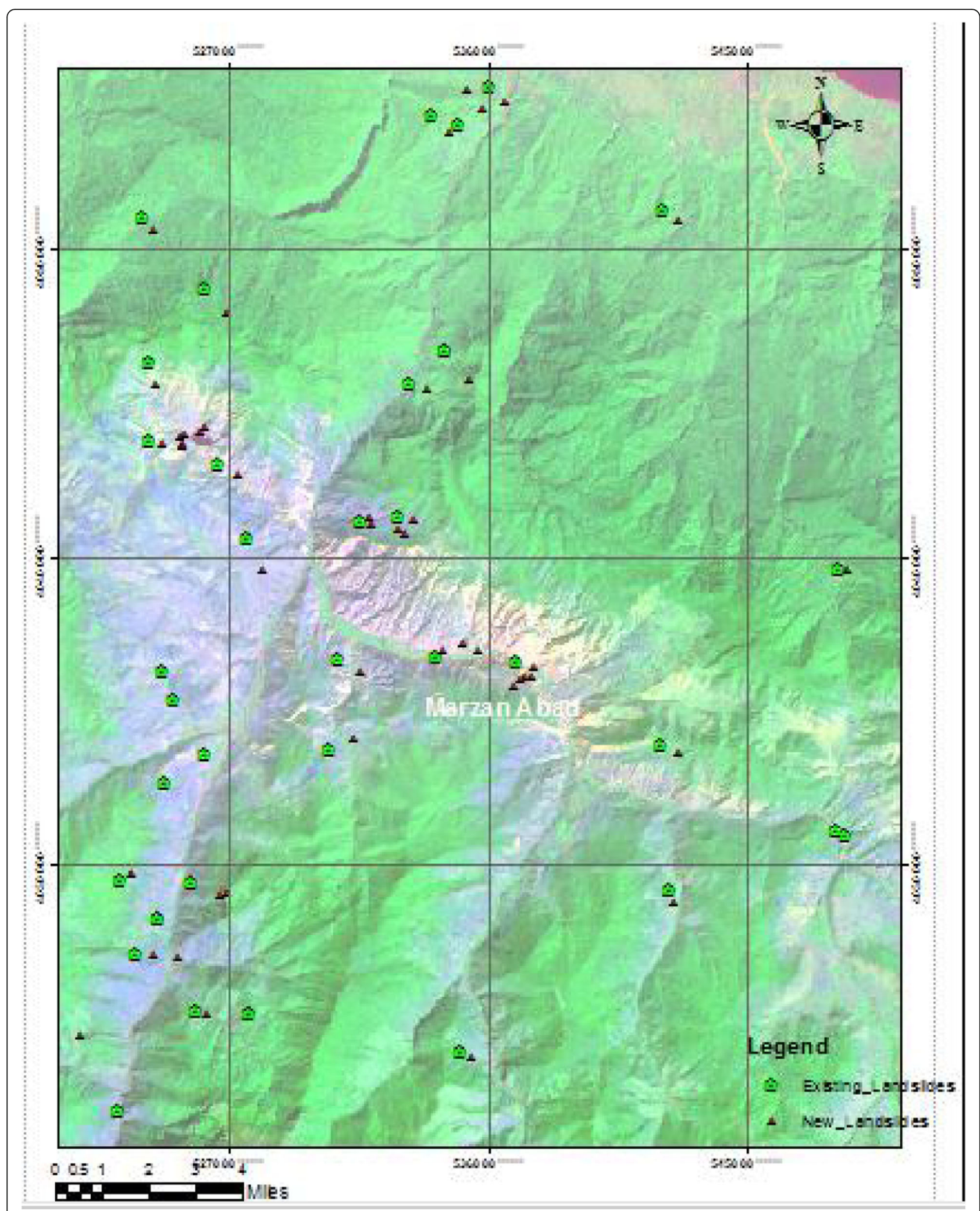

Fig. 9 Geospatial distribution of landslides inventory and recent landslides on the Landsat TM (RGB:742) imagery 
$>800 \mathrm{~m}$ from the road network show a minor relationship with landslide occurrence $(\mathrm{FR}<1)$.

Landslide Susceptibility Index (LSI) calculation shows that the LSI has a minimum range value of susceptibility class of 2.3, and a maximum range value of susceptibility class of 55.7, with an average value of 6.95 and a standard deviation of 5.02 (Table 4). Nevertheless, we prepared the geospatial distribution of updated landslide inventory dataset which illustrated on the Landsat TM; and this improved inventory dataset includes recent landslides, minor-medium and human casualties landslides (Fig. 9). The final landslide susceptibility map in five susceptibility prediction class based on the LSI values (Fig. 10).

Figure 11 shows the evaluated success rate curve is very steep in the first part of the curve. It means an excellent predictive capability. This study found that more than $50 \%$ of the landslides are locating in $3 \%$ of the area where landslide hazards index have a higher rank. Also, about $22 \%$ of the study area has predicted as the most hazardous areas. However, we found that $90 \%$ of landslides are in these regions. The area under the curve (AUC) (Fig. 11) assesses the prediction accuracy, and the total area $=1$ denotes a perfect prediction. In this study area, the ratio is about 0.926 . The study has indicated 92.6\% agreement between the prepared susceptibility map and landslide locations from the existing landslide inventory geospatial distribution map and the field observations. However, it is a very promising result, and we improved the quality of the landslide susceptibility mapping by using the LiDAR high-resolution DEM associated with PFR model.

Figure 12 shows seven success rate prepared by the exclusion of each factors' values from the original susceptibility map. Also, Table 4 depicts statistics of the LSI value for all cases.

This study reveals that by using the effect analysis, we can know the influence of factors on the landslide susceptibility map, qualitatively. However, the selection of positive factors associated with the PFR and a highresolution DEM and its derivatives can improve the prediction accuracy of the landslide susceptibility map. Table 4 shows that geology of the area is the most important and the most effective factor on landslide analysis (AUC ratio $=0.789$ ) in Marzan Abad area. In addition to geology, the roads network (AUC

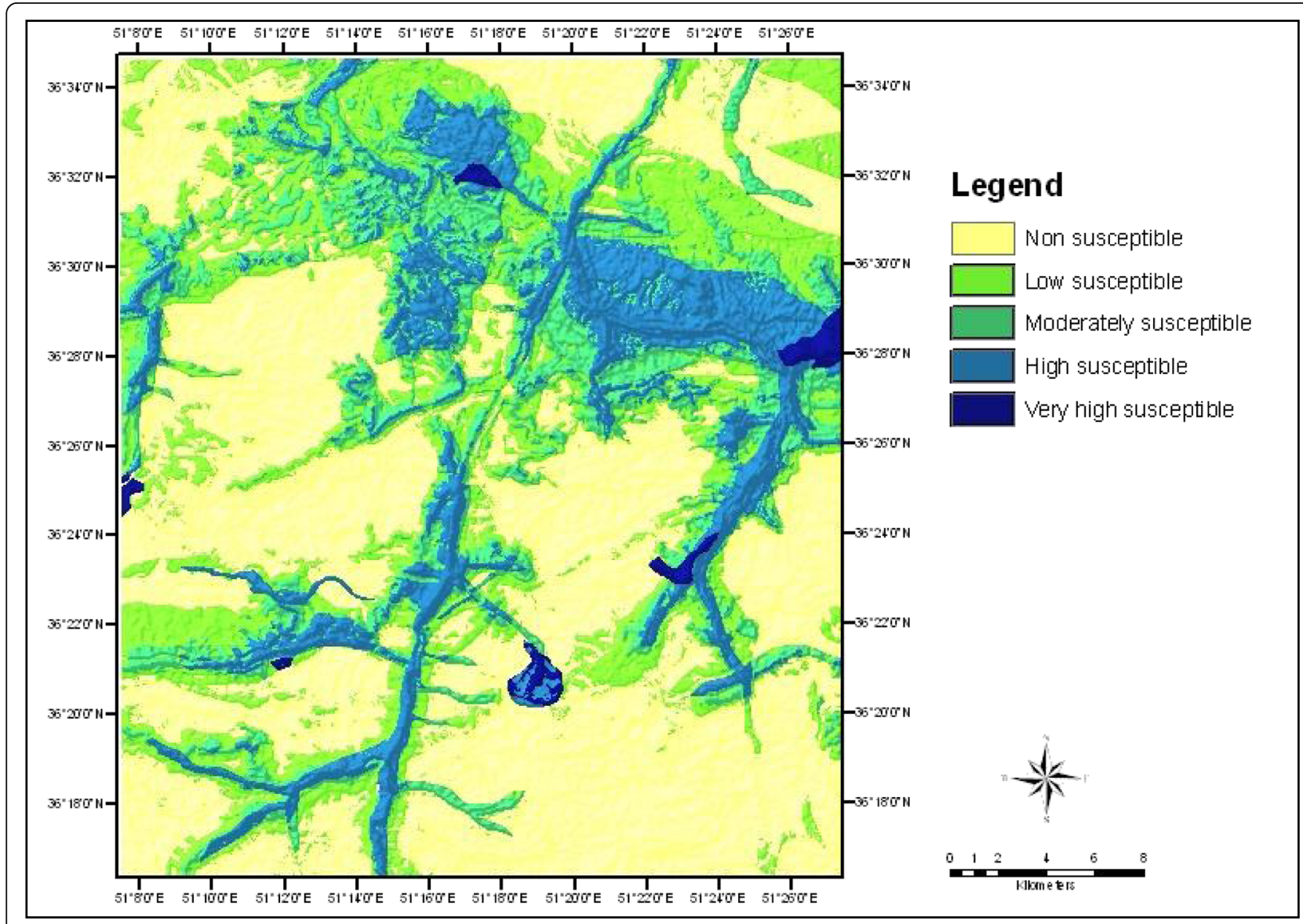

Fig. 10 Landslide susceptibility and hazards prediction map of Marzan Abad area, Central Alborz Mountains 


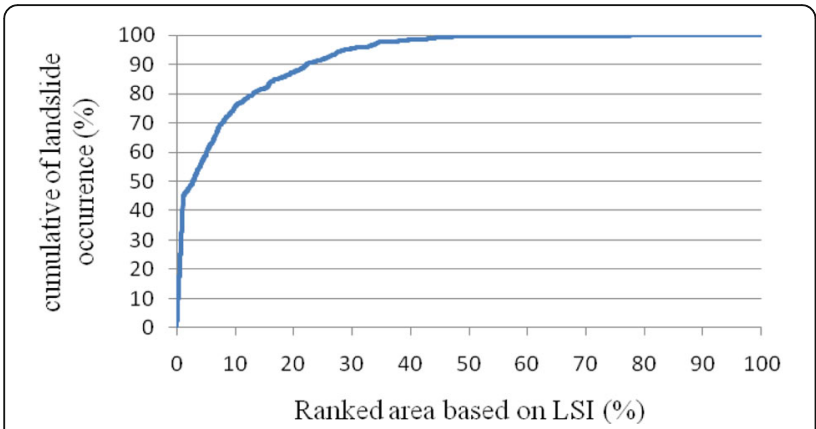

Fig. 11 Showing success rate of the curve

ratio $=0.909)$ and soil (AUC ratio $=0.915)$ have the most influencing factors on the evaluation of landslide susceptibility mapping. Despite from the mentioned factors, all other effective factors are showing a relatively small and a positive effect on landslides analysis (AUC ratio $<0.926$ ). It can be concluded that all selected factors have some positive influence on the landslide hazards analysis and improved landslides prediction.

\section{Conclusion and suggestion}

This study can motivate the Iranian Government to capture the LiDAR point cloud data for development of big data and geodata analytics for the landslide inventory of Iran. We concluded that how LiDAR DEM highresolution impacts the PFR model outcomes and increases the precision and quality of the susceptibility mapping as compared with the ASTER DEM with $15 \mathrm{~m}$ in resolution. As an advanced technique, LiDAR could provide a good set of three-dimensional data with $\mathrm{X}, \mathrm{Y}$ and $\mathrm{Z}$ axis of Marzan Abad area. The PFR model applies on the high-resolution DEM, and its derivative such as slope has provided an improved quality of outcomes of landslide susceptibility mapping in conjunction with the ASTER DEM and Google Earth's images. This study provides detailed information such as color, geologic, and geomorphic using LiDAR data to generate an improved quality of DEM's derivatives to assess and predict landslides.

This study concluded that movements and landslide predisposing factors such as topography are similar to those verified landslides in the past. Therefore, this enables us to predict the future slides occurring in a non-specified time span. This study constructs acceptable relationships between improved landslide inventory (Fig. 9) spatial distribution and influencing factors for landslide susceptibility mapping utilizing PFR model and LiDAR approach extracted a high-resolution DEM. The PFR was applied to study the influence of different earth surface factors on the landslide occurrence and evaluating the landslide susceptibility. This model has advantages such as simplicity, and moreover, inputs, outputs, and calculation process are understandable. Also, a large amount of data can be processed in the GIS environment quickly and easily. Based on the qualitative studies, the influencing factors on the landslide susceptibility map were evaluated to select positive factors and to improve the prediction accuracy of the landslide susceptibility map. It means that the selection of factors is significant to landslide susceptibility mapping. This study emphasizes that the most significance causative factor is geology, soil, and roads network. However, we have identified that other factors have positive influences on the landslide susceptibility analysis.

Nevertheless, this study concluded that the most sensitive classes to landslides in the Central Alborz are: a)

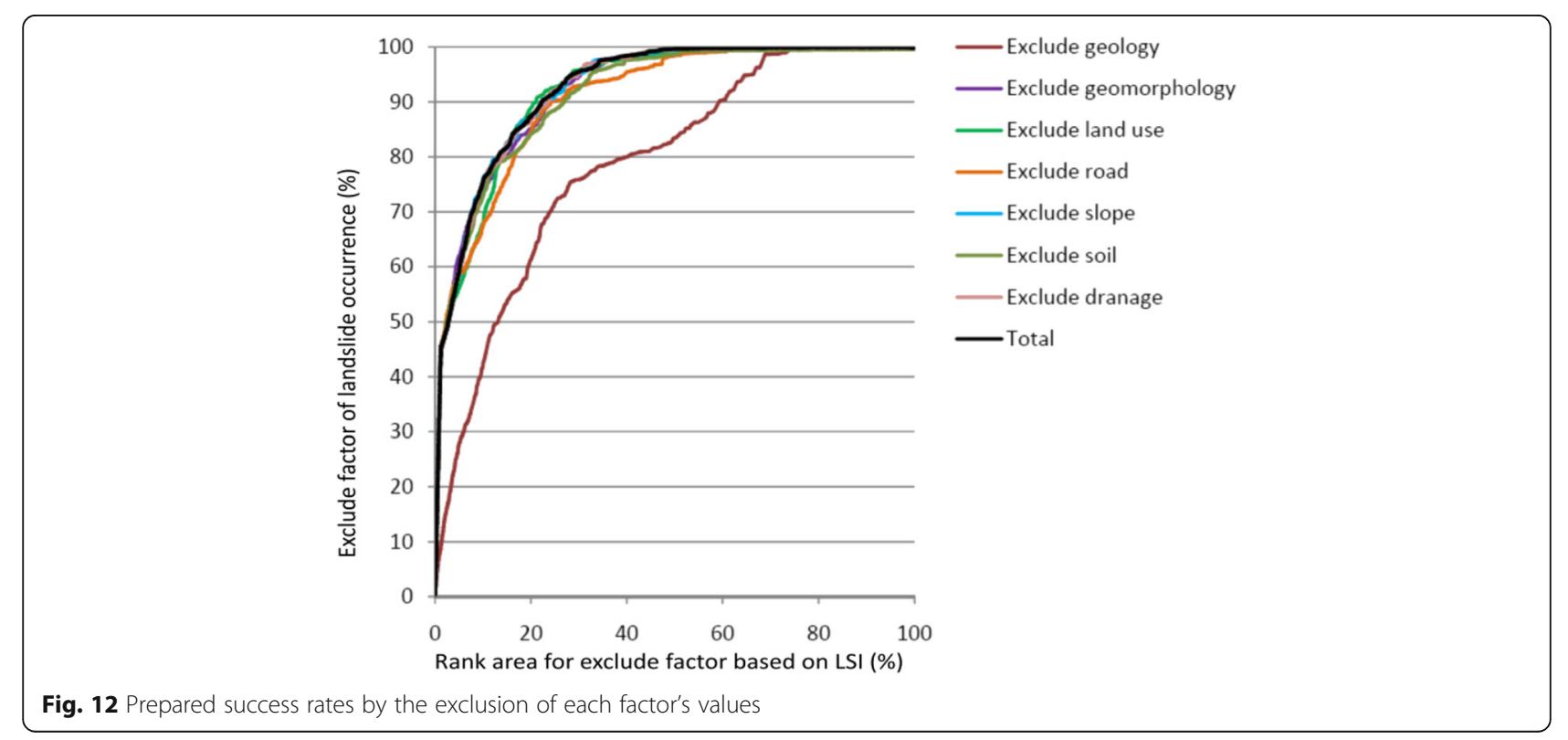


Quaternary deposits, b) Chalus Formation, and c) Nesen Formation. In addition to the above, we have evaluated that areas below 100-m distances to the roads with more than $10^{\circ}$ slope are predictable to landslides. Also, this study brings attentions to decision makers because we have determined the most landslide susceptible areas in deep alluvial soils, deep valleys, debris lands, and the area near water. This study prepared improved landslide susceptible map and it is showing recent landslides on the map. Thus, decisions makers can use it for future operations. However, the information provided by this map can help citizens, planners, and engineers for loss reduction that might have caused from existing and future landslides. This study suggests that factors such as tectonic activities, seismicity, the vulnerability of buildings to be considered for evaluating the PFR model when researchers use LiDAR point cloud data and satellite images. It is because high tectonic activities and earthquakes can trigger landslides.

\section{Acknowledgements}

We identified potential susceptible areas for landslides in Marzan Abad, the Central Alborz Iran. We also improved the quality of landslide evaluation by using the high-resolution of DEM, and we could identify new landslides in the study areas. LiDAR remote sensing data are useful for landslide investigations, particularly when we acquire a high-resolution digital elevation model (DEM). Authors estimate the operational use of the LiDAR technology associated with analytical approaches for landslide studies more often shortly.

This article is a part of the Ph.D. thesis that delivers an integration method of LiDAR data associated with the ASTER DEM and Google Earth's images by applying the PFR model to evaluate landslide analysis, and to increase the quality of susceptibility mapping in Alborz Mountains.

\section{Funding}

This work does not have any funding.

\section{Authors' contributions}

SP organized and structured the full manuscript. He collected the data and evaluated them for use in the GIS environment for analyzing and mapping. He also developed an improved susceptibility map and the inventory dataset. SP did the ground truth and field observation. JL contributed to discussions and structuring the body of the manuscript. He was also responsible for SP's supervision of the Ph.D. thesis. Both authors read and approved the final manuscript.

\section{Competing interests}

The authors declare that they have no competing interests.

\section{Publisher's Note}

Springer Nature remains neutral with regard to jurisdictional claims in published maps and institutional affiliations.

Received: 20 February 2017 Accepted: 20 June 2017

Published online: 10 July 2017

\section{References}

Ali, Syed Ahmad, Kazem Rangzan, and Pirasteh Saied. 2003a. Remote Sensing and GIS study of tectonics and net erosion rates in the Zagros Structural Belt, southwestern Iran. GISciences and Remote Sensing Journal 40 (4): 253-262.

Ali, Syed Ahamad, Rangzan Kazem, and Pirasteh Saied. 2003b. Use of digital elevation model for study of drainage morphometry and identification stability and saturation zones in relations to landslide assessments in parts of the Shahbazan area, SW Iran. Cartography Journal 32 (2): 71-76.

Ali, Syed Ahamad, and S. Pirasteh. 2004. Geological applications of Landsat Enhanced Thematic Mapper (ETM) data and Geographic Information System (GIS): mapping and structural interpretation in south-west Iran, Zagros Structural Belt. International Journal of Remote Sensing 25 (21): 4715-4727.
Al-Rousan, N., P. Cheng, G. Petrie, T. Toutin, and M.J. Valadan Zoej. 1997. Automated DEM extraction and orthoimage generation from SPOT level 1B imagery. Photogrammetric Engineering and Remote Sensing 63: 965-974.

Anbalagan, R. 1992. Landslide hazard evaluation and zonation mapping in mountainous terrain. Engineering Geology 32: 269-277.

Barredo, J.I. A. Benavidesz, J. Hervhl, and C.J.V. Westen. 2000. Comparing heuristic landslide hazard assessment techniques using GIS in the Tirajana basin, Gran Canaria Island. Spain Applied Earth Observation and Geoinformation 2 (1): 9-23.

Binaghi, E., P.A. Brivio, P. Ghezzi, and A. Rampini. 1999. A fuzzy set-based accuracy assessment of soft classification. Pattern Recognition Letters 20: 935-948.

Brunsden, D. 1996. Mass movement, the research frontier and beyond: a geomorphological approach. Geomorphology 7: 85-128.

Carrara, A., M. Cardinali, R. Detti, and F. Guzzetti. 1991. GIS techniques and statistical models in evaluating landslide hazard:Earth surface process. Landform 16 (5): 427-445.

Carrara, A., F. Guzzetti, M. Cardinali, and P. Reichenbach. 1999. Use of GIS technology in the prediction and monitoring of landslide hazard. Natural Hazards 20: 117-135.

Choi, J., H.J. Oh, H.J. Lee, C. Lee, and S. Lee. 2012. Combining landslide susceptibility maps obtained from frequency ratio, logistic regression, and artificial neural network models using ASTER images and GIS. Engineering Geology 124: 12-23.

Derron, M.H., and M. Jaboyedoff. 2010. Preface to the special issue. LIDAR and DEM techniques for landslide monitoring and characterization Nat Hazards Earth Syst Sci 10: 1877-1879.

Dietrich, E.W., R. Reiss, M.L. Hsu, and D.R. Montgomery. 1995. A process-based model for colluvial soil depth and shallow landsliding using digital elevation data. Hydrological Processes 9: 383-400.

Donati, L., and M.C. Turrini. 2002. An objective method to rank the importance of the factors predisposing landslides with the GIS methodology application to an area of the Apennines (Valneria; Perugia, Italy). Engineering Geology 63: $277-290$

Duan, J., and G.E. Grant. 2000. Shallow landslide delineation for steep forest watersheds based on topographic attributes and probability analysis, Terrain Analysis - Principles and Applications. In , ed. J.P. Wilson and J.C. Gallant, 311-329. New York: John Wiley \& Sons.

Eeckhaut, M., and J.P. Van Den. 2007. Use of LIDAR-derived images for mapping old landslides under forests. Earth Surface Processes and Landforms 32: 754-769.

Evans, Jeffrey S., Hudak Andrew T. Faux Russ, and M.S. Smith Alistair. 2009. Discrete Return Lidar in Natural Resources: Recommendations for Project Planning, Data Processing, and Deliverables. Remote Sensing Journal 1: 776-794. doi:10.3390/rs1040776.

Glenn, Nancy F., David R. Streutker, Chadwick D. John, Glenn D. Thackray, and Stephen J. Dorsch. 2006. Analysis of LiDAR-derived topographic information for characterizing and differentiating landslide morphology and activity. Geomorphology 73: 131-148.

Guzzetti, F., A. Carrara, M. Cardinali, and P. Reichenbach. 1999. Landslide hazard evaluation: a review of current techniques and their application in a multi-scale study. Central Italy, Geomorphology 31: 181-216.

Guzzetti, F., P. Reichenbach, M. Cardinali, M. Galli, and F. Ardizzone. 2005. Probabilistic landslide hazard assessment at the basin scale. Geomorphology 72: 272-299.

Haugerud, R.A., D.J. Harding, S.Y. Johnson, J.L. Harless, C.S. Weaver, and B.L. Sherrod. 2003. High-resolution LIDAR topography of the Puget Lowland, Washington. GSA Today 13 (6): 4-10.

Jebur, Mustafa Neamah, Pradhan Biswajeet, and Shafapour Tehrany Mahyat. 2014. Optimization of landslide conditioning factors using very high-resolution airborne laser scanning (LiDAR) data at catchment scale. Remote Sensing of Environment 152: 150-165.

Jaboyedoff, Michel, Oppikofer Thierry, Abella'n Antonio, Marc-Henri Derron, Loye Alex, Metzger Richard, and Pedrazzini Andrea. 2012. Use of LIDAR in landslide investigations: a review. Natural Hazards 61: 5-28. doi:10.1007/s1 1069-010-9634-2.

Kamp, Ulrich, Bolch Tobias, and Olsenholler Jeffrey. 2003. DEM generation from aster satellite data for geomorphometric analysis of Cerro Sillajhuay, Chile/Bolivia, ASPRS 2003, Annual Conference Proceedings May 2003.

Lee, S., J. Choi, and K. Min. 2004. Probabilistic landslide hazard mapping using GIS and remote sensing data at Boun, Korea. International Journal of Remote Sensing 125 (11): 2037-2052.

Lee, S., and N.T. Dan. 2005. Probabilistic landslide susceptibility mapping in the Lai Chau province of Vietnam: focus on the relationship between tectonic fractures and landslides. Environmental Geology 48: 778-787. 
Lee, S., and B. Pradhan. 2006. Probabilistic landslide hazards and risk mapping on Penang Island, Malaysia. Earth system science 115 (6): 661-672.

Lee, S., J.-H. Ryu, J.-S. Won, and H.-J. Park. 2004. Determination and application of the weights for landslide susceptibility mapping using an artificial neural network. Engineering Geology 71: 289-302.

Lee, Moung-Jin, Park Inhye, and Saro Lee. 2014. Forecasting and validation of landslide susceptibility using an integration of frequency ratio and neurofuzzy models: a case study of Seorak mountain area in Korea. Environmental Earth Science DOI. doi:10.1007/s12665-015-4048-9.

Liu, Jin-King, Hsiao Kuo-Hsin, and Shih Peter Tian-Yuan. 2012. A geomorphological model for landslide detection using airborne LiDAR data. Journal of Marine Science and Technology 20 (6): 629-638.

Luzi, L., F. Pergalani, and M.T.J. Terlien. 2000. Slope vulnerability to earthquakes at subregional scale, using probabilistic techniques and geographic information systems. Engineering Geology 58: 313-336.

McKean, J., and J. Roering. 2003. Objective landslide detection and surface morphology mapping using high-resolution airborne laser altimetry. Geomorphology 57: 331-351.

Metternicht, G., L. Hurni, and R. Gogu. 2005. Remote sensing of landslides: An analysis of the potential contribution to geo-spatial systems for hazard assessment in mountainous environments. Remote Sensing of Environment 98: 284-303.

Nichol, J.E., and M.S. Wong. 2005. Satellite remote sensing for detailed landslide inventories using change detection and image fusion. International Journal of Remote Sensing 26: 1913-1926.

Niculită, Mihai. 2016. Automatic landslide length and width estimation based on the geometric processing of the bounding box and the geomorphometric analysis of DEMs. Natural Hazards and Earth System Sciences 16: 2021-2030. doi:10.5194/nhess-16-2021-2016.

Pack, R.T., and D.G. Tarboton. 2004. Stability index mapping (SINMAP) applied to the prediction of shallow translational landsliding. Geophysical Research Abstracts 6: 05122.

Pfeifer, N., A. Kostli, and K. Kraus. 1998. Interpolation and filtering of laser scanner data-implementation and first results. International Archives of Photogrammetry. Remote Sensing and Spatial Information Sciences 32 (part3/1): 153-159.

Pirasteh, S., K. Woodbridge, and S.M. Rizvi. 2009. Geo-information technology (GiT) and tectonic signatures: the River Karun \& Dez, Zagros Orogen in south-west Iran. International Journal of Remote Sensing 30 (1-2): 389-404.

Pirasteh, Saied, Pradhan Biswajeet, and Safari H. 2011. Coupling of DEM and remote sensing based approaches for semi-automated detection of regional geo-structural features in Zagros Mountain, Iran, Arabian Journal of Geosciences DOI 10.1007/s12517-011-0361-0.

Pirasteh, Saied, Li Jonathan, and Attarzadeh Iman 2015. Implementation of the damage index approach to rapid evaluation building resistance for earthquakes, Earth Science Informatics (DOI) 10.1007/s12145-014-0204-0.

Pirasteh, Saied, and Li Jonathan. 2016. Landslides investigations from geoinformatics perspective: quality, challenges, and recommendations, Geomatics, Natural Hazards and Risk Journal 1-18. DOI: 10.1080/19475705. 2016.1238850.

Pradhan, Biswajeet, and Pirasteh Saied. 2010. Comparison between prediction capabilities of neural network and fuzzy logic techniques for landslide susceptibility mapping. Disaster Advances Journal 3 (2): 19-25.

Roering, J.J., L.L. Stimely, B.H. Mackey, and D.A. Schmidt. 2009. Using DInSAR airbone LIDAR and archival air photos to quantify landsliding and sediment transport. Geophysical Research Letters 36: L19402. doi:10.1029/2009 GL040374.

Sarkar, S., and D.P. Kanungo. 2004. An integrated approach for landslide susceptibility mapping using remote sensing and GIS. Photogrammetric Engineering \& Remote Sensing 70 (5): 617-625.

Shoaei, Z., G. Shoaei, and R. Emamjomeh. 2005. Interpretation of the Mechanism of Motion and Suggestion of Remedial Measures Using GPS Continuous Monitoring Data, Landslides Risk Analysis and Sustainable Disaster Management. In , ed. K. Sassa, H. Fukuoka, F. Wang, and G. Wang, 327-335. Berlin Heidelberg: Springer.

Schulz, William H. 2004. Landslides mapped using LIDAR imagery, Seattle, Washington, U.S. Geological Survey Open-File Report 2004-1396: 1-13.

Schulz, William H. 2007. Landslide susceptibility revealed by LIDAR imagery and historical records, Seattle, Washington. Engineering Geology 89: 67-87.

Streutker, D.R., and N.F. Glenn. 2006. LiDAR measurement of sagebrush steppe vegetation heights. Remote Sensing of Environment 102: 135-145.

Su, Cheng, Wang Lili, Wang Xizhi, Huang Zhicai, and Zhang Xiaocan 2015. Mapping of rainfall-induced landslide susceptibility in Wencheng,
China, using support vector machine, Nat Hazards DOI 10.1007/s11069014-1562-0.

Su, J.G., and E.W. Bork. 2006. Influence of vegetation, slope and LiDAR sampling angle on DEM accuracy. Photogrammetric Engineering and Remote Sensing 72: 1265-1274.

Varnes, D.J. 1978. slope movement types and process. In: landslides, analysis, and control, Transportation Research Board Special Report 176: 11-33.

Watts, P. 2004. Probabilistic predictions of landslide tsunamis off Southern California. Marine Geology 203: 281-301.

Westen, Van C.J., and Terlien M.T.1996. Deterministic landslide hazard analysis in GIS. A case study from Manizales (Colombia), Earth Surface Processes and Landforms 2:853-868.

Westen, Van Cees J., Castellanos Enrique, and Sekhar L. Kuriakose. 2008. Spatial data for landslide susceptibility, hazard, and vulnerability assessment: An overview. Engineering Geology 102: 112-131.

Yilmaz, I. 2010. The effect of the sampling strategies on the landslide susceptibility mapping by conditional probability (CP) and artificial neural network (ANN). Environmental Earth Science 60: 505-519.

Zhou, C.H., C.F. Lee, J. Li, and Z.W. Xu. 2002. On the spatial relationship between landslides and causative factors on Lantau Island, Hong Kong. Geomorphology 43: 197-207.

Zhou, G., T. Esaki, M. Mitani, M. Xie, and J. Mori. 2003. Spatial probabilistic modelling of slope failure using integrated GIS Monte Carlo simulation approach. Engineering Geolology 68: 373-386.

\section{Submit your manuscript to a SpringerOpen ${ }^{\circ}$ journal and benefit from:}

- Convenient online submission

- Rigorous peer review

- Open access: articles freely available online

- High visibility within the field

- Retaining the copyright to your article

Submit your next manuscript at springeropen.com 